\title{
EVALUASI TINGKAT KETERPAKAIAN KOLEKSI PUSTAKA DI PERPUSTAKAAN SMAN 1 LABUAPI
}

\author{
Baiq Rohiyatun', Menik Aryani ${ }^{2}$ \\ Program Studi Administrasi Pendidikan, FIPP UNDIKMA \\ Email: rbaiq@yahoo.co.id
}

\begin{abstract}
Abstrak: Perpustakaan dapat dikatakan berhasil jika banyak digunakan oleh pemustakanya. Salah satu aspek penting untuk membuat perpustakaan itu banyak digunakan pemustaka adalah ketersediaan koleksi yang memenuhi kebutuhan penggunanya. Kegiatan evaluasi terhadap bahan pustaka perlu dilakukan agar dapat mencapai tujuan Perpustakaan SMAN 1 Labuapi pada bulan Januari sampai bulan Desember 2018 memiliki 447 judul buku dengan 4.140 eksemplar buku. Berbagai macam bahan pustaka yang terdapat disirkulasi terdiri dari buku teks dan buku untuk pengembangan ilmu (bahan pustaka umum). Untuk mengetahui bahan pustaka apa saja yang dibutuhkan pengguna perpustakaan di awal tahun ajaran perpustakaan menyebarkan formulir penambahan bahan pustaka keseluruh guru masing-masing mata pelajaran untuk mengisi judul buku yang diperlukan, baik itu buku wajib maupun buku pengayaan informasi bagi pengguna. Jumlah judul dan eksemplar juga belum memenuhi rasio jumlah siswa dan buku ditetapkan pemerintah. Strategi promosi yang dilakukan dengan membangun komunikasi dengan pengguna, merupakan pemanfaatan ilmu komunikasi dalam segala kegiatan promosi, oleh karena itu diperlukan kemampuan dalam berkomunikasi dengan pengguna, lingkungan, fasilitas dan bahan pustaka yang ada. Analisis kekuatan dan kelemahan koleksi diperlukan untuk mengetahui kedalaman dan kelengkapan koleksi dalam subjek tertentu. Kemudian elemen-elemen yang perlu diperhatian dalam mengembangkan bahan pustaka perpustakaan adalah perpustakaan harus mengkaji siapa penggunanya, mengkaji layanan jasa informasi apa yang diinginkan pengguna, mengkaji benefit yang dicari pemustaka, menganalisa kekuatan, kelemahan, dan peluang yang dimikili perpustakaan, serta jasa yang ditawarkan, mengkaji kekuatan dan kelemahan kompetisi, memahami perbedaan antara perpustakaan dan kompetisi dan membuat perencanaan yang dapat diaplikasikan untuk mencapai tujuan.
\end{abstract}

Kata Kunci: Evaluasi, Koleksi Pustaka, Pustakawan, Promosi

LATAR BELAKANG

Perpustakaan adalah urat nadi ilmu pengetahuan yang dapat memberikan konstribusi dalam meningkatkan wawasan dan kualitas seseorang. Dengan demikian, perpustakaan dalam menyediakan koleksi atau bahan pustaka harus benar-benar memperhatikan kebutuhan pengguna. Untuk itu perpustakaan tidak hanya menyimpan tetapi juga mengolah dan menata koleksi yang ada secara sistematis agar dapat digunakan oleh pengguna perpustakaan secara maksimal. Perpustakaan dapat dikatakan berhasil jika banyak digunakan oleh pemustakanya. Salah satu aspek penting untuk membuat perpustakaan itu banyak digunakan pemustaka adalah ketersediaan koleksi yang memenuhi kebutuhan penggunanya. Karena itu tugas utama perpustakaan adalah berupaya membangun koleksi sesuai dengan kebutuhan penggunanya. Untuk melihat apakah perpustakaan sudah membangun koleksi sesuai dengan tujuan dan bagaimana kualitas koleksi yang telah dikembangkan sudah sesuai dengan standar, perlu diadakan suatu analisis dan evaluasi koleksi. Evaluasi koleksi adalah kegiatan menilai koleksi perpustakaan baik dari segi ketersediaan koleksi itu bagi pengguna maupun pemanfaatan koleksi itu oleh pengguna (Yulia, 2009:3.34 ). Perpustakaan identik dengan adanya koleksi.

$$
\text { Lasa Hs (2009:63) menjelaskan }
$$
bahwa "koleksi merupakan nafas perpustakaan. Perpustakaan tanpa koleksi ibarat manusia yang sesak nafas, tersengalsengal dalam menghirup udara yang bisa saja lama kelamaan tidak bisa bernafas. Untuk itu keberadaan koleksi perpustakaan sekolah harus diperhatikan, agar perpustakaan sekolah dapat menjalankan fungsinya sebagai sumber informasi yang menyediakan dan memberikan informasi yang cepat, up to date, terpercaya dan tepat bagi pemustaka". Masruri (2007:35) mengatakan bahwa "koleksi buku yang dimiliki pihak perpustakaan sekolah umumnya adalah 
masih sangat memprihatinkan dan jauh dari memuaskan. Rata-rata perpustakaan sekolah hanya mengacu buku-buku yang berkaitan dengan mata pelajaran dan diktat". Jarang ditemukan buku-buku jenis fiksi, bibliografi dsb, padahal ketersediaan buku di perpustakaan sangat erat keterkaitannya dengan program peningkatan minat baca. Koleksi perpustakaan sekolah harus lengkap, terdiri dari beragam subyek dan memadai untuk menunjang tujuan dan program sekolah di bidang pendidikan dan pengajaran. Untuk itu dalam pengadaan koleksi perpustakaan harus selalu berupaya memilih dan membuat keputusan yang terbaik dalam menetapkan koleksi yang akan diadakan menyesuaikan dengan kebutuhan pemustakanya.

Untuk perpustakaan sekolah yang menjadi tolak ukur utama baiknya koleksi perpustakaan adalah koleksi yang memiliki relevansi dengan kebutuhan pemustaka. Kajian mengenai pemanfaatan koleksi dapat diarahkan pada dua hal, yang pertama adalah evaluasi terhadap pengguna perpustakaan sedangkan yang kedua adalah evaluasi terhadap koleksi itu sendiri. Dengan demikian evaluasi koleksi perpustakaan menjadi sangat penting untuk dilakukan secara berkesinambungan karena dapat membantu perpustakaan sekolah dalam memahami secara komprehensif tentang koleksi yang dimiliki serta seberapa besar kebutuhan pemustaka yang dapat mereka penuhi sebagai tujuan dari kegiatan pengembangan koleksi yang dilaksanakan. Kegiatan evaluasi merupakan upaya untuk menilai daya guna dan hasil guna bahan pustaka dalam memenuhi kebutuhan pemustaka. Evaluasi harus selalu dilaksanakan dengan teratur supaya bahan pustaka yang tersedia sesuai dengan perubahan dan perkembangan kebutuhan pemustaka. Kegiatan evaluasi terhadap bahan pustaka perlu dilakukan agar dapat mencapai tujuan yaitu: (1) mengetahui mutu, lingkup, dan kedalaman koleksi, (2) menyesuaikan koleksi dengan tujuan dan program lembaga induk, (3) mengikuti perubahan, perkembangan, sosial budaya, ilmu dan teknologi, (4) meningkatkan nilai informasi, (5) mengetahui kekuatan dan kelemahan koleksi, (6) menyesuaikan kebijakan penyiangan. Perpustakaan melakukan evaluasi untuk beberapa alasan, seperti untuk mengembangkan program pengadaan yang cerdas dan realistis berdasarkan pada data koleksi yang sudah ada, untuk menjadi bahan pertimbangan pengajuan anggaran untuk pengadaan koleksi berikutnya, dan untuk menambah pengetahuan staf pengembangan koleksi terhadap keadaan koleksi.

Adapun teknik evaluasi yang dapat dilakukan ada dua secara kuantitatif dan kualitatif. Cara kuantitatif dilakukan dengan pengumpulan data statistik, dan dari data statistik itu dapat diperoleh informasi yang cukup mengenai koleksi yang ada. Informasi koleksi yang diperlukan untuk pengumpulan data statistik sekurang-kurangnya harus meliputi jumlah judul, jumlah eksemplar, kelas pustaka, bentuk bahan perpustakaan, bahasa bahan perpustakaan, asal bahan perpustakaan, tahun terbit.

Dari kegiatan evaluasi yang dilakukan diharapkan dapat menjawab pertanyaan apakah kekuatan dari koleksi perpustakaan yang dikelola dan seberapa efektif perpustakaan memanfaatkan dana pengembangan koleksi dan seberapa besar manfaat koleksi terhadap pengguna yang dilayani. Serta untuk mengetahui keadaan koleksi perpustakaan dibandingkan dengan perpustakaan yang setara.

\section{KAJIAN PUSTAKA}

Keterpakaian koleksi

Kohn (2013:88) metode evaluasi koleksi berbasis keterpakaian koleksi berfokus pada permintaan pengguna. Permintaan ini berasal dari data sirkulasi yang berasal dari dalam perpustakaan sendiri maupun yang berasal dari luar perpustakaan yang biasa disebut dengan Inter Librarian Loan.

Jain (1969:245) metode yang digunakan untuk melihat keterpakaian koleksi ada 2 metode yang pertama adalah 
dengan memilih sampel buku dari total koleksi pada perpustakaan. Setelah itu mengecek tentang pemakaian koleksi tersebut yang dicacat oleh perpustakaan. Metode yang kedua adalah metode yang menggunakan semua populasi menjadi sampel penelitian. Selain mencacat pemakaiannya peneliti juga akan mencacat karakteristik yang dimiliki oleh koleksi. Karakteristiknya berupa subjek dan umur buku saat berada di perpustakaan. Masih menurut Jain (1969:248,249) pemakaian koleksi untuk pemakaian ditempat indikator checklist meliputi (1) nomor klasifikasi, (2) volume koleksi (jika ada), (3) nomor eksemplar dari koleksi (jika ada), tanggal dari peminjaman koleksi.

Thompson (1991:443) menyatakan

bahwa pengukuran konsep pemanfaatan perpustakaan dapat diukur dengan tiga indikator yakni intensitas penggunaan, frekwensi penggunaan, dan jumlah koleksi yang digunakan. Ketiga indikator tersebut mempunyai penjelasan dan tujuan sebagai berikut : 1) Intensitas Penggunaan (intensity of use): Hal ini menunjukkan tentang sejauh mana keandalan dan kehebatan koleksi yang dimiliki oleh perpustakaan. Intensitas penggunaan dilihat dari kunjungan yang dilakukan oleh pengguna perpustakaan. Jika pengguna teratur pergi ke perpustakaan maka bisa disimpulkan jika informasi yang di perpustakaan dibutuhkan dan permanfaat bagi pengguna; 2) Frekuensi penggunaan (frequency of use): Bertujuan untuk menunjukkan seberapa sering pengguna menggunakan koleksi untuk memenuhi kebutuhan informasinya. Pemfaatan ini tidak hanya dari penggunaan koleksi namun juga dari pemanfaatan fasilitas yang ada di perpustakaan; 3) Jumlah yang digunakan (diversity of software pachage used): Menujukkan tentang sejauh mana ketergantungan pengguna terhadap koleksi yang ada di perpustakaan. Dalam pemanfaatan koleksi pengguna tidak hanya datang untuk meminjam koleksi namun juga untuk menggunakan koleksi di tempat.

\section{Koleksi}

Koleksi merupakan suatu hal yang sentral dalam perpustakaan. Perpustakaan berbasis pelayanan dan salah satu yang dilayankan adalah koleksi. Menurut Sutarno (2006:83) koleksi perpustakaan harus mencakup bahan pustaka yang terpilih, informasi yang terkandung harus cocok dengan keperluan dan dapat dibaca/didengar dan dimengerti oleh masyarakat pemakai. Jika perpustakaan bisa memenuhi kebutuhan informasi pengguna maka proses transfer informasi akan lebih mudah sehingga perpustakaan akan bisa menjadi jembatan antara informasi dan masyarakat.

\section{METODE PENELITIAN}

\section{Tahapan Penelitian}

Ada beberapa tahapan penelitian yang akan dilakukan oleh peneliti dalam penelitian ini, untuk lebih detail maka di bawah ini akan disampaikan secara rinci tahap-tahap penelitian dalam penelitian ini yaitu: (1) Peneliti mengajukan judul yang akan menjadi tema penelitian kepada LPPM IKIP Mataram, (2) studi pendahuluan, untuk mengetahui issue yang urgen, unik menarik dan actual peneliti lakukan selama 12 hari yaitu pada tanggal 2- 14 Maret 2019 yang kemudian dideskripsikan dalam bentuk proposal, (3) Melaksanakan kegiatan penelitian dan, (4) Membuat laporan hasil penelitian.

\section{Pendekatan dan Jenis Penelitian}

Jenis penelitian yang digunakan adalah pendekatan kuantitatif yang berupaya memberikan deskripsi tentang keterpakaian koleksi pustaka di Perpustakaan SMAN 1 Labuapi. Metode yang digunaan adalah metode dokumentasi. Metode dokumentasi adalah catatan tertulis tentang berbagai kegiatan atau peristiwa. Melalui penelitian diusahakan mengumpulkan data dan dituangkan dalam bentuk laporan dan uraian. Dengan metode ini peneliti berusaha melukiskan keadaan yang sebenarnya, baik pada pengolahan dan analisis data. Penelitian deskriptif mencoba mencari deskripsi yang 
tepat dan cukup dari semua aktivitas, objek, proses dan manusia. Melalui metode dokumentasi, peneliti memeriksa secara langsung catatan tertulis yang ada tentang keterpakian koleksi pustaka yang terdapat pada data sirkulasi. Hasil pengolahan dan analisisi data dituangkan dalam table. Pengkajian pola penggunaan koleksi sebagai sarana untuk mengevaluasi koleksi semakin populer. Dua asumsi dasar dalam kajian pengguna/penggunaan adalah kecukupan koleksi terkait langsung dengan pemanfaatannya oleh pengguna dan statistik sirkulasi memberikan gambaran yang layak mewakili penggunaan koleksi. Metode ini digunakan sebagai usaha untuk mengetahui pemanfaatan koleksi pustaka di perpustakaan SMAN 1 Labuapi. Evaluasi keterpakian koleksi pustaka dilakukan di Perpustakaan SMAN 1 Labuapi. Objek penelitian adalah koleksi pustaka pada layanan sirkulasi yang terdapat di Perpustakaan SMAN 1 Labuapi.Variabel yang menjadi sumber data dalam penelitian ini adalah koleksi pustaka di Perpustakaan SMAN 1 Labuapi yang berkaitan dengan tingkat keterpakian koleksi oleh pemustaka. Indikator keterpakaian koleksi terdiri dari peminjaman untuk di bawa pulang. Metode pengumpulan data yang digunakan dalam penelitian ini adalah metode terpusat pada pengguna berdasarkan pada kajian sirkulasi. Kegiatan sirkulasi adalah salah satu metode evaluasi yang dilakukan dengan memantau data sirkulasi. Dasar kajian sirkulasi adalah memberikan gambaran mengenai kegunaan dan kerterpakain koleksi oleh pemustaka. Metode pengumpulan data ini diharapkan dapat mengetahui keterpakaian koleksi umum pada layanan sirkulasi di Perpustakaan SMAN 1 Labuapi. Teknik analisis data yang digunakan adalah teknik analisis deskriptif. Analisis deskriptif adalah penelitian yang menyelidiki, mengumpulkan dan menyusun data penelitian dalam bentuk tabel.

HASIL DAN PEMBAHASAN Gambaran Umum Perpustakaan
Gambaran umum Perpustakaan SMAN 1 Labuapi Perpustakaan SMAN 1 Labuapi adalah perpustakaan yang dikelola oleh 2 orang yang terdiri dari Kepala perpustakaan yang merangkap sebagai Guru PNS dan Pengelola yang merangkap staf administrasi.

Visi dan Misi Perpustakaan SMAN 1 Labuapi

Visi : Menjadi perpustakaan yang berkualitas, mencerdaskan dan menyenangkan.

Misi :

1. Menjadikan perpustakaan sebagai jantungnya pendidikan di sekolah;

2. Memberikan pelayanan yang baik santun dan ramah;

3. Menjadikan perpustakaan sebagai tempat belajar yang menyenangkan;

4. Melaksanakan kegiatan membaca dan menulis secara optimal yang berorientasi pada pencapaian budaya baca.

\section{Struktur Organisasi Perpustakaan SMAN 1 Labuapi}

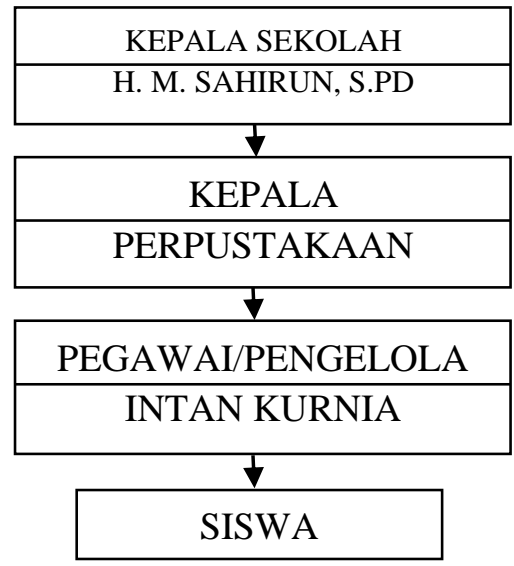

Untuk pelayanan sirkulasi menganut sistem terbuka dengan tujuan memungkinkan para pemustaka secara langsung memilih dan mengambil sendiri bahan pustaka yang dikehendaki. Berbagai macam bahan pustaka yang terdapat disirkulasi terdiri dari buku teks dan buku untuk pengembangan ilmu (bahan pustaka umum). Menurut jenis pekerjaan pelayanan sirkulasi meliputi peminjaman, pengembalian, penagihan, dan pemberian sanksi. Pelayanan sirkulasi adalah 
suatu kegiatan pelayanan pencatatan dalam pemanfaatan dan penggunaan koleksi bahan pustaka dengan tepat guna dan tepat waktu untuk kepentingan pemustaka. Pelayanan sirkulasi ditujukan untuk memungkinkan pemustaka menggunakan bahan pustaka secara tepat guna, mengetahui bahan pustaka yang dipinjamkan, mengetahui siapa yang meminjam bahan pustaka, peminjam mengembalikan bahan pustaka yang dipinjam, mendapatkan data-data kuantitatif kegiatan pelayanan sirkulasi.

Layanan peminjaman bertugas meminjamkan bahan pustaka untuk dibawa pulang dan dalam batas waktu tertentu harus dikembalikan. Peminjaman dan pengembalian bahan pustaka dilakukan oleh petugas perpustakaan. Dan tidak semua bahan pustaka dapat dipinjamkan kepada pemustaka yang menjadi anggotanya. Bahan pustaka seperti buku referensi, majalah, surat kabar dan karya ilmiah tidak bisa dibawa pulang. Bahan pustaka tersebut hanya dibaca di tempat atau di foto kopi.

Layanan peminjaman bertugas meminjamkan bahan pustaka untuk dibawa pulang dan dalam batas waktu tertentu harus dikembalikan. Peminjaman dan pengembalian bahan pustaka dilakukan oleh petugas perpustakaan. Dan tidak semua bahan pustaka dapat dipinjamkan kepada pemustaka yang menjadi anggotanya. Bahan pustaka seperti buku referensi, majalah, surat kabar dan karya ilmiah tidak bisa dibawa pulang. Bahan pustaka tersebut hanya dibaca di tempat atau di foto kopi.

Sivitas akademika yang dapat memanfaatkan layanan peminjaman adalah semua sivitas akademika yang ada di lingkungan sekolah dan tidak berlaku bagi orang lain. Bagi pemustaka yang melanggar ketentuan yang berlaku akan dikenakan sanksi. Jumlah eksemplar yang boleh dipinjam oleh siswa dan guru sama. Jumlah pinjaman maksimal bagi siswa dan guru adalah empat. Masa peminjaman bagi siswa dan guru adalah satu minggu. Masa peminjaman dapat diperpanjang lagi apabila tidak ada anggota lain yang memesannya.
Susunan koleksi di rak baik buku teks dan karya lain yang diberi nomor panggil (call number) pada punggungnya disusun secara sistematis berdasarkan nomor panggil tersebut yang memuat tiga informasi: nomor urut buku; tiga huruf nama pengarang, dan huruf pertama judul karya. Perpustakaan yang memberikan pelayanan yang baik, harus mampu berusaha memberikan berbagai sumber informasi yang dibutuhkan pengguna. Perpustakaan SMAN 1 Labuapi pada bulan Januari sampai bulan Desember 2018 memiliki 447 judul buku dengan 4.140 eksemplar buku.

Tabel 1. Jumlah Koleksi Buku Perpustakaan SMAN 1 Labuapi sampai Bulan Juni tahun 2018

\begin{tabular}{|c|c|c|}
\hline \multirow{2}{*}{ No. Klas } & \multicolumn{2}{|c|}{ Jumlah } \\
\hline & Judul & Eksemplar \\
\hline 000 (Karya Umum) & 47 & 300 \\
\hline 100 (Filsafat) & 30 & 350 \\
\hline 200 (Agama) & 45 & 620 \\
\hline 300 (Ilmu-Ilmu Sosial) & 100 & 1025 \\
\hline 400 (Bahasa) & 35 & 150 \\
\hline 500 (Ilmu-Ilmu Murni) & 35 & 250 \\
\hline 600 (Ilmu Terapan/Teknologi) & 30 & 340 \\
\hline $\begin{array}{l}700 \text { (Kesenian, Olahraga, } \\
\text { Hiburan) }\end{array}$ & 35 & 350 \\
\hline 800 (Kesusasteraan) & 45 & 430 \\
\hline 900 (Geografi, Sejarah) & 45 & 325 \\
\hline Jumlah & 447 & 4. 140 \\
\hline
\end{tabular}

Jika dilihat dari tabel di atas koleksi yang paling banyak judul dan eksemplarnya adalah klas 300 yaitu ilmu sosial yang terdiri dari 100 judul dengan 1025 eksemplar. Diikuti urutan kedua klas 000 yaitu karya umum yang terdiri dari 47 judul dengan 300 eksemplar. Diikuti urutan ketiga klas 200 yaitu Agama yang terdiri dari 45 judul dengan 620 eksemplar. Diikuti urutan keempat klas 800 yaitu kelas Kesusasteraan yang terdiri dari 45 judul dengan 430 eksemplar. Diikuti urutan kelima klas 900 yaitu Geografi dan Sejarah yang terdiri dari 45 judul dengan 325 eksemplar. Diikuti urutan enam yaitu koleksi kelas Kesenian, Olahraga dan Hiburan yang terdiri dari 35 judul dengan 350 eksemplar. Diikuti urutan ketujuh klas 500 yaitu ilmu-ilmu Murni yang terdiri dari 35 judul dengan 250 eksemplar. Diikuti urutan ke delapan klas 400 yaitu Bahasa yang terdiri dari 35 judul dengan 150 eksemplar. Diikuti urutan kesembilan 100 
yaitu Filsafat yang terdiri dari 30 judul dengan 350 eksemplar. Diikuti urutan ke sepuluh klas 600 yaitu Terapan/Treknologi yang teridiri dari 30 judul dengan 340 eksemplar. Diikuti urutan ke sebelas klas 200 yaitu agama yang terdiri dari 1.475 judul dengan 11.576 eksemplar.

Pengadaan koleksi perpustakaan merupakan kegiatan penting di perpustakaan, karena dalam kegiatan tersebut, bahan-bahan pustaka dianalisis, dipilih dan ditetapkan untuk dibeli atau diadakan oleh perpustakaan. Pengadaan koleksi perpustakaan SMAN 1 Labuapi dilakukan dengan teknik pembelian, hadiah dan sumbangan. Pengadaan koleksi lebih banyak dilakukan dengan teknik pembelian. Sebelum membeli koleksi, perpustakaan melakukan beberapaa tahap persiapan pembelian koleksi. Adapun tahap-tahap persiapannya sebagai berikut. (1) perpustakaan melakukan seleksi. Pada umumnya, bahan seleksi bersumber dari kurikulum, RPP, saran dari pemustaka (Guru dan siswa), dan katalog penerbit; (2) perpustakaan membuat daftar usulan tambahan buku. Daftar ini kemudian diserahkan kemasing-masing guru mata pelajaran setiap kelas untuk diisi judul buku yang dibutuhkan. Perioritas ditentukan oleh masing-masing guru mata pelajaran dengan menempatkan judul yang menjadi prioritas di urutan teratas. Untuk menyesuaikan jumlah pembelian dengan besarnya dana yang ada, pembelian dilakukan berdasarkan urutan prioritas; (3) setelah diisi oleh masingmasing guru mata pelajaran, daftar pengadaan tersebut diserahkan kembali ke perpustakaan; (4) kemudian, perpustakaan membuat daftar pengadaan buku; dan (5) selanjutnya, pembelian koleksi,

Untuk mengetahui bahan pustaka apa saja yang dibutuhkan pengguna perpustakaan di awal tahun ajaran perpustakaan menyebarkan formulir penambahan bahan pustaka keseluruh guru masing-masing mata pelajaran untuk mengisi judul buku yang diperlukan, baik itu buku wajib maupun buku pengayaan informasi bagi pengguna. Tapi sayangnya hanya sebagian kecil saja guru yang mengisi dan mengembalikan keperpustakaan. Pada hal kalau semua guru mengisi dan mengembalikan keperpustakaan akan memudahkan perpustakaan dalam memilih bahan pustaka yang tepat. Karena guru adalah subjek spesialis yang lebih mengetahui bahan pustaka yang relefan dengan mata pelajaran yang bersangkutan. Diharapkan dimasa yang akan datang perlunya kerjasama yang baik antara perpustakaan dengan guru. Setelah buku diadakan dan dicek secara fisik oleh pustakawan atau panitia pengadaan, buku diserahkan ke perpustakaan untuk diolah.

Koleksi umum yang dimiliki Perpustakaan masih belum dapat mememuhi kebutuhan pengguna jika dilihat dari mata pelajaran yang harus didukungnya Meskipun demikian koleksi yang ada cukup membantu aktivitas belajar mengajar karena setiap tahunnya perpustakaan mengembangkan koleksinya dengan bahan-bahan pustaka yang terbaru. Dari pengamatan penulis pada koleksi yang berhubungan dengan sebagian mata pelajaran tertentu ditemukan bahwa ketersedian koleksi yang mendukung mata pelajaran belum sepenuhnya tercukupi. Jumlah judul dan eksemplar juga belum memenuhi rasio jumlah siswa dan buku ditetapkan pemerintah. Hal ini disebabkan oleh seperti umumnya masalah yang terjadi pada institusi akademis yaitu masalah anggaran dan birokrasi masih menjadi kendala utama perpustakaan untuk mengelola pengadaan koleksi sampai pada tahap yang ideal serta manajemen perlindungan koleksi sampai pada tahap yang maksimal.

\section{Tingkat Keterpakaian Koleksi Umum di Perpustakaan SMAN 1 Labuapi}

Tingkat keterpakian koleksi nomor kelas 000-900 dan buku fiksi untuk di bawa pulang dapat dilihat pada tabel 2 .

\section{Tabel 2. Data Statistik Peminjaman Koleksi Umum Bulan Januari-Desember} 2018

\begin{tabular}{|l|c|}
\hline \multicolumn{1}{|c|}{ Bulan } & $\begin{array}{c}\text { Jumlah Koleksi yang } \\
\text { dipinjam }\end{array}$ \\
\hline Januari & 25 \\
\hline
\end{tabular}




\begin{tabular}{|c|c|}
\hline Februari & 30 \\
\hline Maret & 20 \\
\hline April & 27 \\
\hline Mei & 0 \\
\hline Juni & 0 \\
\hline Juli & 18 \\
\hline Agustus & 19 \\
\hline September & 0 \\
\hline Oktober & 0 \\
\hline Nopember & 26 \\
\hline Desember & 20 \\
\hline Jumlah & 185 \\
\hline
\end{tabular}

Sumber : Data Statistik Peminjaman Koleksi Umum Tahun 2018

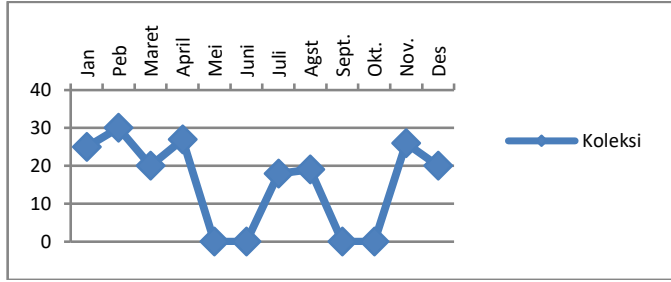

\section{Gambar 1: Diagram Pluktuasi Peminjaman Koleksi Umum Bulan Januari-Desember 2018}

Dari data di atas dapat di ketahui bahwa peminjam koleksi umum untuk dibawa pulang dari Bulan Januari sampai Desember 2018 adalah 185 eksemplar. Jika dilihat dari data statistik peminjaman tahun 2018 yang peminjaman koleksinya banyak hanya bulan-bulan tertentu yaitu 185 eksemplar. Sedangkan yang peminjaman koleksinya tidak ada hal ini disebabkan karena siswa sedang Ujian Akhir Semester dan libur semester. Berdasarkan data tersebut dapat diketahui rata-rata peminjaman koleksi perbulan yaitu 15 eksemplar. Melihat jumlah rata-rata peminjaman koleksi sangat jauh dari harapan

Jika dilihat dari penyebab rendah atau kurangnya keterpakian koleksi berdasarkan wawancara dengan pemustaka adalah ada yang mengatakan bahwa koleksi sirkulasi kurang up to date, sebagian koleksi sirkulasi tidak sesuai dengan mata pelajaran. Tidak ditemukannya koleksi juga mempengaruhi tingat keterpakaian.Kurang selektif dalam pembelian koleksi, ini terlihat dari buku dirak yang jarang digunakan oleh pemustaka. Buku yang dibutuhkan jumlah eksemplaranya jauh lebih sedikit di bandingkann dengan jumlah eksemplar koleksi yang kurang digunakan.

Untuk meningkatkan keterpakian koleksi, salah satu upaya yang penting di lakukan adalah promosi. Dengan promosi, perpustakaan dapat melakukan berbagai kegiatan seperti display, bedah buku, resensi sehingga koleksi yang sebelumnya tidak dimanfaatkan atau sama sekali tidak pernah dimanfaatkan dapat diketahui oleh pemustaka. Agar koleksi sirkulasi dapat dimanfaatkan secara optimal, perpustakaan perlu melakukan kegiatan promosi.

Promosi perpustakaan merupakan usaha agar pepustakaan dikenal dan digunakan atau keterpakaian perpustakaan menjadi tinggi. Berdasarkan wawancara dengan pustakawan (31/8/2019) mengenai kegiatan promosi yang dilakukan perpustakaan SMAN 1 Labuapi sebagai berikut.

Kegiatan promosi yang dilakukan perpustakaan SMAN 1 Labuapi dengan membuat sepanduk berisi tentang informasi yang bisa mereka dapatkan kalau menjadi anggota perpustakaan. Mengirim judul-judul buku baru untuk ditempel dan di dalam perpustakaan ada lemari display tempat memajangkan bahan pustaka yang baru. Melalui kegiatan pendidikan pemakai dan juga melakukan kegiatan seminar tentang perpustakaan.

Strategi promosi yang dilakukan dengan membangun komunikasi dengan pengguna, merupakan pemanfaatan ilmu komunikasi dalam segala kegiatan promosi, oleh karena itu diperlukan kemampuan dalam berkomunikasi dengan pengguna, lingkungan, fasilitas dan bahan pustaka yang ada. Beberapa sikap dalam berkomunikasi dapat ditunjukkan dengan kemampuan memiliki wawasan yang luas, tingginya integritas dan kemampuan dalam berkomunikasi. Kemudian dapat juga dilakukan dengan membangun kerjasama dengan pihak ketiga. Pada dasarnya tidak satupun perpustakaan yang mampu 
memberikan layanan berupa pemenuhan semua kebutuhan pengguna, oleh karena itu perlu dibangun kerjasama terutama dalam layanan promosi.

\section{Kekuatan dan Kelemahan Koleksi Perpustakaan SMAN 1 Labuapi}

Berdasarkan hasil pengamatan, pendataan serta penafsiran terhadap koleksi di SMAN 1 Labuapi. Jika dilihat dari jumlah koleksi yang dimiliki perpustakaan SMAN 1 Labuapi berdasarkan subyek pada tabel 1 . Dari tabel 1 tersebut dapat dilihat bahwa koleksi yang paling banyak tersedia adalah subjek ilmu Sosial dengan 100 judul dengan 1025 eksemplar. Dari data tersebut dapat terlihat bahwa perpustakaan SMAN 1 Labuapi kekuatan koleksinya berada pada subjek-subjek ilmu sosial yang terdiri dari subjek statistik umum, ilmu politik (politik dan pemerintah), ilmu ekonomi, ilmu hukum, administrasi negara, masalah-masalah sosial, pendidikan, perdagangan, komunikasi, adat istiadat dan kebiasaan. Penulis menilai bahwa koleksi ilmu sosial yang paling banyak jumlah judul dan eksemplarnya di karenakan sesuai dengan matapelajaran.

Subjek dari ilmu sosial yang paling dominan itu adalah subjek pendidikan. Juduljudul yang tersedia untuk subjek ilmu sosial cukup bervariasi sehingga kondisinya lebih baik dari kelas lainnya. Koleksi pada subjek ini memiliki potensi untuk terus dikembangkan sebagai koleksi inti perpustakaan. Analisis ini senada dengan apa yang diungkpkan oleh kepala perpustakaan yang menyatakan bahwa koleksi subjek ilmu sosial yang di dalamnya ada subjek pendidikan. Jika dilihat dari tingkat keterpakian koleksi, terlihat bahwa koleksi yang paling banyak di pinjam oleh pemustaka dari bulan Januari sampai Desember 2018 adalah koleksi dengan subjek ilmu-ilmu sosial sebanyak 185 eksemplar.

Kelemahan koleksi yang dimiliki perpustakaan SMAN 1 Labuapi berdasarkan subjek yang sedikit dimiliki perpustakaan yaitu subjek selain Ilmu-ilmu social. Berdasarkan hasil wawancara penulis dengan Kepala Perpustakaan SMAN 1 Labuapi tentang kelemahan bahwa belum ada tenaga pengelola yang memahami ilmu perpustakaan, sehingga pada penataan perpustakaan tidak dilaksananakan secara maksimal. Hal ini terlihat dari sistem klasifikasi yang tidak sesuai, penataan koleksi yang tidak rapi, kurang diperhatikan kebersihan ruangan perpustakaan, layanan sirkulasi yang tidak sesuai, tidak ada slip peminjaman pada masing-masing bahan pustaka, dan tidak ada kartu anggota perpustakaan.

Analisis kekuatan dan kelemahan koleksi diperlukan untuk mengetahui kedalaman dan kelengkapan koleksi dalam subjek tertentu. Kemudian elemen-elemen yang perlu diperhatian dalam mengembangkan bahan pustaka perpustakaan adalah perpustakaan harus mengkaji siapa penggunanya, mengkaji layanan jasa informasi apa yang diinginkan pengguna, mengkaji benefit yang dicari pemustaka, menganalisa kekuatan, kelemahan, dan peluang yang dimikili perpustakaan, serta jasa yang ditawarkan, mengkaji kekuatan dan kelemahan kompetisi, memahami perbedaan antara perpustakaan dan kompetisi dan membuat perencanaan yang dapat diaplikasikan untuk mencapai tujuan.

Akan tetapi banyaknya jumlah koleksi sebuah perpustakaan sekolah bukan menjadi tolak ukur yang paling utama bagi idealnya sebuah perpustakaan. Dalam hal ini Ratcliffe (dalam Hardi, 2005) membedakan large library dan great library. Bagi Ratcliffe perpustakaan yang memiliki jumlah koleksi yang besar (large library) bukan faktor yang menentukan dalam hal pemanfaatan koleksi perpustakaan. Besarnya nilai koleksi perpustakaan (great library) dalam artian koleksi memiliki relevansi dengan kebutuhan pemustaka adalah faktor utama yang akan menentukan tingkat pemanfaatan koleksi oleh sivitas akademika. Kriteria yang paling mendasar bagi perpustakaan UNP adalah koleksi memenuhi kebutuhan informasi primer pemustakanya.

Relevansi koleksi dengan kebutuhan 
informasi di lingkungan sekolah khususnya SMAN 1 Labuapi adalah sebuah desain konseptual yang mengarah pada terbentuknya koleksi inti yang harus ada. Oleh karena itu, perpustakaan harus memahami kebutuhan informasi sivitas akademika, yakni bahan literatur apa yang seharusnya dibaca dan apa yang secara faktual dibaca oleh pemustaka. Disisi lain rendahnya tingkat kedalaman dan kelengkapan koleksi dari segi kualitas, jumlah koleksi yang tidak terlampau banyak bila dibandingkan dengan jumlah pemustaka menjadi faktor utama kurangnya daya dukung koleksi. Untuk itu perlu penekanan pengadaan bahan literatur yang mutakhir mengingat perkembangan ilmu yang cukup pesat.

Di harapkan manajemen perpustakaan perlu segera melakukan pembuatan kebijakan pengembangan koleksi secara tertulis sebagai panduan yang mengarahkan prioritas penguatan koleksi inti perpustakaan dan melakukan pembenahan manajemen pengelolaan koleksi secara bertahap. Pembenahan ini dilakukan agar koleksi perpustakaan dapat mendukung kegiatan belajar mengajar. Pada kenyataannya, sebagian besar perpustakaan sekolah di Indonesia tidak dapat memenuhi kebutuhan informasi para penggunanya dan dihadapkan dengan masalah sulitnya memperkirakan kondisi koleksi di tiap-tiap perpustakaan.

Keadaan tersebut menurut Hardi (2005) dipengaruhi oleh beberapa faktor. (1) minimnya anggaran perpustakaan yang menyebabkan kebutuhan informasi aktual tidak dapat dipenuhi secara langsung. Kondisi ini menjadi lebih buruk apabila pengelola perpustakaan tidak memiliki kebijakan prioritas pengembangan koleksi yang jelas. (2) komunikasi antara guru, siswa dan pustakawan tidak berjalan secara baik sehingga dalam pembelian koleksi perpustakaan, penilaian subjektif pustakawan menjadi dominan.(3) manajemen pada masing-masing perpustakaan sekolah tidak pernah melakukan evaluasi koleksi secara menyeluruh sehingga analisis kekuatan dan kelemahan koleksi tidak dapat diketahui secara jelas.

\section{KESIMPULAN}

Perpustakaan SMAN 1 Labuapi pada bulan Januari sampai bulan Desember 2018 memiliki 447 judul buku dengan 4.140 eksemplar buku. Untuk pelayanan sirkulasi menganut sistem terbuka dengan tujuan memungkinkan para pemustaka secara langsung memilih dan mengambil sendiri bahan pustaka yang dikehendaki. Berbagai macam bahan pustaka yang terdapat disirkulasi terdiri dari buku teks dan buku untuk pengembangan ilmu (bahan pustaka umum). Sivitas akademika yang dapat memanfaatkan layanan peminjaman adalah semua sivitas akademika yang ada di lingkungan sekolah dan tidak berlaku bagi orang lain. Bagi pemustaka yang melanggar ketentuan yang berlaku akan dikenakan sanksi. Jumlah eksemplar yang boleh dipinjam oleh siswa dan guru sama. Pengadaan koleksi perpustakaan merupakan kegiatan penting di perpustakaan, karena dalam kegiatan tersebut, bahan-bahan pustaka dianalisis, dipilih dan ditetapkan untuk dibeli atau diadakan oleh perpustakaan. Pengadaan koleksi perpustakaan SMAN 1 Labuapi dilakukan dengan teknik pembelian, hadiah dan sumbangan. Untuk mengetahui bahan pustaka apa saja yang dibutuhkan pengguna perpustakaan di awal tahun ajaran perpustakaan menyebarkan formulir penambahan bahan pustaka keseluruh guru masing-masing mata pelajaran untuk mengisi judul buku yang diperlukan, baik itu buku wajib maupun buku pengayaan informasi bagi pengguna. Strategi promosi yang dilakukan dengan membangun komunikasi dengan pengguna, merupakan pemanfaatan ilmu komunikasi dalam segala kegiatan promosi, oleh karena itu diperlukan kemampuan dalam berkomunikasi dengan pengguna, lingkungan, fasilitas dan bahan pustaka yang ada. Analisis kekuatan dan kelemahan koleksi diperlukan untuk mengetahui kedalaman dan kelengkapan 
koleksi dalam subjek tertentu. Kemudian elemen-elemen yang perlu diperhatian dalam mengembangkan bahan pustaka perpustakaan adalah perpustakaan harus mengkaji siapa penggunanya, mengkaji layanan jasa informasi apa yang diinginkan pengguna, mengkaji benefit yang dicari pemustaka, menganalisa kekuatan, kelemahan, dan peluang yang dimikili perpustakaan, serta jasa yang ditawarkan, mengkaji kekuatan dan kelemahan kompetisi, memahami perbedaan antara perpustakaan dan kompetisi dan membuat perencanaan yang dapat diaplikasikan untuk mencapai tujuan.

\section{DAFTAR PUSTAKA}

Arikunto, Suharsimi, 2010. Prosedur Penelitian : Suatu Pendekatan Praktik. Jakarta : Rhineka Cipta.

Aslicha, Lilik, Bambang Prasetyo dan Prasetya Irawan, 2010. Metode Penelitian Sosial. Jakarta : Universitas Terbuka.

Blagden, J \& J Harrington, 1990. How good is your library?, a review of approach to the evaluation of libarary information service. London:Aslib.

Departemen pendidikan nasional RI, 2004. Perpustakaan Perguruan Tinggi : buku pedoman Ed.3. Jakarta : Departemen Pendidikan Nasional RI Direktorat Jenderal Pendidikan Tinggi.

Evans, Edward G. and Margaret Zarnosky Saponaro, 2005. Developing Library and Information Center Collection. London : Libriries Unlimited.

Harahap, Irma Efrida. 2010. Hubungan Ketersediaan Koleksi dengan Penggunaan Koleksi pada Perpustakaan Universitas Negeri Padang. Medan : Departemen Studi Perpustakaan dan Informasi Fakultas Ilmu Budaya Universitas Sumatera Utara

Jain, A. K., 1969. Sampling and Data Collection Methods for a Book-Use Study. Chicago : The University of Chicago Press.

Lasa, HS. 2005. Manajemen Perpustakaan.
Yogyakarta: Gama Media.

Sugiyono. 2010. Metode Penelitian Kuantitatif dan Kualitatif dan R \& D. Bandung : Alfabeta.

Sutarno. 2006. Perpustakaan dan Masyarakat. Jakarta : Sagung Seto.

Saleh, Abdul Rahman dan Rita Komalasari, 2010. Manajemen Perpustakaan. Jakarta : Universitas Terbuka

Thompson, Ronald L, 1991. Personal Cumputing : Toward a Conceptual Model of Utilization. MIS Quarterly. Vol 15 No.1

Yulia, Yuyu dan Janti Gristinawati Sujana, 2009. Pengembangan Koleksi. Jakarta: Universitas Terbuka

Evan, G. Edward. 2005. Developing Library and Information Center Collections. Fifth Edition. Colorado: Libraries Unlimited.

Lasa, 2005. Manajemen Perpustakaan. Yogyakarta: Gama Media.

Sulistyo-Basuki.2010. Pengantar Ilmu Perpustakaan. Jakarta: Universitas Terbuka.

Yulia, Yuyu dan Janti Gristinawati Sujana.2009. Pengembangan Koleksi. Jakarta : Universitas Terbuka. 